\title{
A Study on the Structural Stability of the Peptide 2.05-Helix by Infrared Absorption Spectroscopy
}

\author{
M. De Zotti ${ }^{1}$, B. Di Napoli' ${ }^{2}$ C. Mazzuca ${ }^{2}$, A. Palleschi' ${ }^{2}$, G. M. L. Messina ${ }^{3}$, \\ G. Marletta ${ }^{3}$, and F. Formaggio ${ }^{1}$ \\ ${ }^{1}$ Department of Chemistry, University of Padova, Padova, I-35131, Italy; ${ }^{2}$ Department of Sciences and \\ Chemical Technologies, University of Rome "Tor Vergata", Rome, I-00133, Italy; ${ }^{3}$ Laboratory for Molecular \\ Surfaces and Nanotechnology, Department of Chemical Sciences, University of Catania, Catania, I-95125, Italy
}

\section{Introduction}

$\mathrm{C}^{\alpha}$-Tetrasubstituted residues are known to induce the onset of helical structures in peptides with sequences even as short as 4-5 residues [1]. Due to their rigidity, such conformationally-constrained oligopeptides are often employed as spacers [2], or as simple models to study the stability and behavior of biologically-relevant helical structures [3]. $\mathrm{C}^{\alpha, \alpha}$-diethylglycine (Deg) is one of such residues. Its homo-peptides were found to adopt a rather unusual helical conformation, the 2.05-helix, also known as fully-extended conformation [4]. The 2.05-helix, characterized by $\phi$ and $\psi$ backbone torsion angles of $180^{\circ}$, is indeed the longest conformation a peptide of a given number of residues can adopt. Recently, we found that Deg homo-peptides are also able to switch their conformation between $2.0_{5^{-}}$ and 310 -helices in response to a change in solvent polarity [5]. Here, we present preliminary results obtained in our FT-IR study on the stability and behavior of the (Deg) $)_{n} 2.0_{5}$-helix in the solid state. We

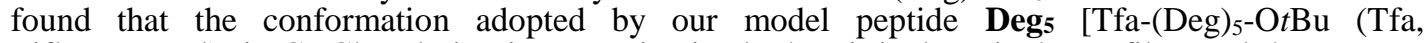
trifluoroacetyl)] in $\mathrm{CDCl}_{3}$ solution is not maintained when it is deposited as a film, and that we can govern the conformational equilibrium by applying an electric field (EF) during the deposition process [6].

\section{Results and Discussion}

To study the influence of both the physical state and an applied electric field $(\mathrm{EF}=7.5 \mathrm{~V} / \mathrm{m})$ on the 3Dstructure adopted by Deg$_{5}$, we performed FTIR experiments under different experimental conditions. We chose to employ this spectroscopy because peptides have several IR active vibrational modes, some of which (amide I at $1700-1600 \mathrm{~cm}^{-1}$ and amide II at $1600-1480 \mathrm{~cm}^{-1}$ ) are sensitive to the variation of secondary structure [7].

Experimentally, the FTIR spectrum of Deg 5 in $\mathrm{CDCl}_{3}$ solution at $0.1 \mathrm{mM}$ peptide concentration has been obtained in the transmission mode using a $\mathrm{NaCl}$ cell, while that of $\mathbf{D e g}_{\mathbf{5}}$ as a film has been recorded using an ATR apparatus equipped with a $\mathrm{ZnSe}$ cell. In the latter case, $\mathrm{CDCl}_{3}$ peptide solutions were deposited on the cell, and the solvent allowed to evaporate in the presence or absence of an external EF.

Analysis of the amide I and II regions of the Deg FTIR spectrum as a film was performed and compared with the spectrum of the same peptide in $\mathrm{CDCl}_{3}$ solution. In solution, the number, position, and relative intensities of the absorption bands in the two spectral regions are diagnostic of the presence of a fully-extended conformation [8,9]. One clear proof for the onset of a $2.0_{5}$-helix is indeed the presence in the amide I region of the FTIR spectrum of two, strong peaks near 1650 and $1670 \mathrm{~cm}^{-1}$, as shown in Figure 1-I (dashed line).

For the peptide film, however, the FTIR spectrum in the amide I region is clearly different (Figure $1-\mathrm{I}$. The peptide changes its most populated conformation, assuming a mainly $\alpha / 3_{10}$-helical structure (a strong absorption band for $\alpha / 3_{10}$-helices is usually seen in the $1655-1670 \mathrm{~cm}^{-1}$ range). The minor component at about $1680 \mathrm{~cm}^{-1}$ may be assigned to type-III $\beta$-turn and/or non $\mathrm{H}$-bonded carbonyl groups $[10,11]$. An inspection of the intensities of the amide II bands (Figure 1-II), in comparison with those in the amide I region, confirms this conclusion, as the strong band near $1490 \mathrm{~cm}^{-1}$, expected for a fullyextended conformation, is much less evident in the peptide film.

When an external electric field is applied during the process of film formation, the FTIR spectrum of Deg 5 seems to indicate a somewhat increased helical content. This conclusion stems from a decrease in the intensity of the band centered at about $1680 \mathrm{~cm}^{-1}$, attributed to the 2.05 -helix, and a concomitant 
shift of the band in the amide II region to higher wavenumbers with respect to $1500 \mathrm{~cm}^{-1}$, confirming the reduced presence of fully-extended structures.

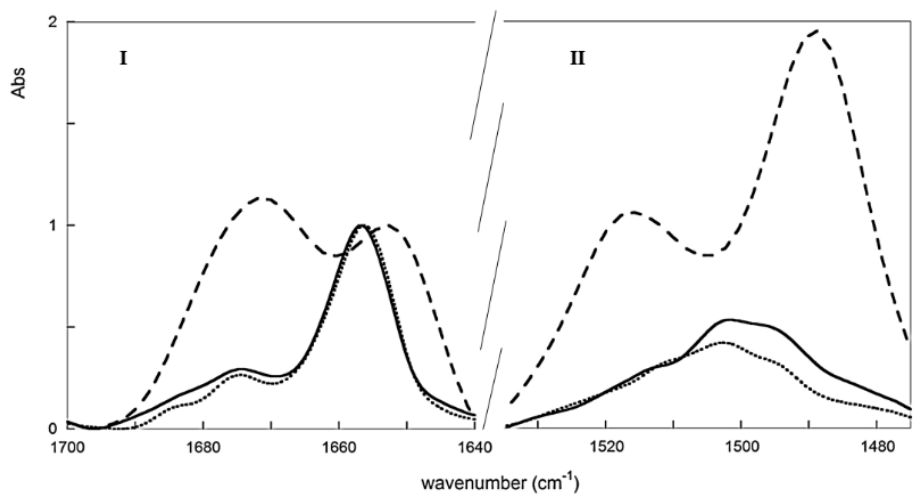

Fig. 1. Amide I (panel I) and Amide II (panel II) regions of the FTIR normalized spectra of Deg 5 $(0.1 \mathrm{mM})$ in $\mathrm{CDCl}_{3}$ solution (- - ) and in film obtained by a $\mathrm{CDCl}_{3}$ peptide solution in the absence (-) and presence (...) of an external electric field. Curves are normalized to the intensity at $1656 \mathrm{~cm}^{-1}$ for film, and at $1653 \mathrm{~cm}^{-1}$ for solution spectra.

\section{Acknowledgments}

We gratefully acknowledge MIUR for financial support (FIRB project RBFR13RQXM: Peptide-based Conformational Switches: Design, Synthesis, and Applications).

\section{References}

1. Toniolo, C., Crisma, M., Formaggio, F., Peggion, C. Biopolymers (Pept. Sci.) 60, 396-419 (2001), http://dx.doi.org/10.1002/1097-0282(2001)60:6<396::AID-BIP10184>3.0.CO;2-7

2.Toniolo, C., Crisma, M., Formaggio, F., Peggion, C. Broxterman, Q.B., Kaptein, B. Biopolymers (Pept. Sci.) 76, 162-176 (2004), http://dx.doi.org/10.1002/bip.10575

3.Parthasarathy, R., Chaturvedi, S., Kuantee, G. Prog. Biophys. Mol. Bio. 64, 1-54 (1995), http://dx.doi.org/10.1016/0079-6107(95)00009-7

4.Peggion, C., Moretto, A., Formaggio, F., Crisma, M., Toniolo, C. Biopolymers (Pept. Sci.) 100, 621-636 (2013), http://dx.doi.org/10.1002/bip.22267

5.Peggion, C., Crisma, M., Toniolo, C., Formaggio, F. Tetrahedron 68, 4429-4433 (2012), http://dx.doi.org/10.1016/j.tet.2011.12.087

6.Toschi, F., Lugli, F., Biscarini, F., Zerbetto, F. J. Phys. Chem. B 113, 369-376 (2009), http://dx.doi.org/10.1021/ct1001335

7.Krimm, S., Bandekar, J. Adv. Protein Chem. 38,181-364 (1986), http://dx.doi.org/10.1016/S00653233(08)60528-8

8.Formaggio, F., Crisma, M., Ballano, G., Peggion, C., Venanzi, M., Toniolo, C. Org. Biomol. Chem. 10, 24132421 (2012), http://dx.doi.org/10.1039/c2ob06863j

9.Maekawa, H., Ballano, G., Toniolo, C. and Ge, N.-H. J. Phys. Chem. B 115, 5168-5182 (2011), http://dx.doi.org/10.1021/jp105527n

10. Pispisa, B., Palleschi, A., Stella, L., Venanzi, M., Mazzuca, C., Formaggio, F., Toniolo, C., Broxterman, Q.B. J. Phys. Chem. B 106, 5733-5738 (2002), http://dx.doi.org/10.1021/jp012599a

11. Kennedy, D.F., Crisma, M., Toniolo, C., Chapman, D. Biochemistry 30, 6541-6548 (1991), http://dx.doi.org/10.1021/bi00240a026 